\title{
A Rat Model of Thyroid Hormone-Induced Bone Loss: Effect of Antiresorptive Agents on Regional Bone Density and Osteocalcin Gene Expression
}

\author{
ANNIE W.C. KUNG and F. NG
}

\begin{abstract}
Thyroid hormone has been shown to stimulate bone resorption. Both endogenous hyperthyroidism and exogenous thyroxine suppressive therapy have been associated with reduction in bone mineral density (BMD), but the patholophysiology of thyroxine-induced bone loss is not well understood. First we studied the effect of $L-T_{4}(0.1-0.3$ $\mu \mathrm{g} / \mathrm{g}$ body weight ip/day) on bone turnover in rats by measuring regional BMDs and osteocalcin mRNA. Next we determined whether antiresorptive agents (calcitonin $1 \mu \mathrm{U} / \mathrm{g}$ ip/day or sodium etidronate given cyclically at $10 \mu \mathrm{g} / \mathrm{g}$ po for 3 consecutive days out of every week) could prevent bone loss. Groups of 10 male Sprague-Dawley rats each weighing $320-350 \mathrm{~g}$ were studied before and after 3 weeks of treatment. $L-T_{4}$ treatment resulted in reduction in BMDs in the lumbar spine, tail, and femur as measured by dual energy $X$-ray absorptiometry, but there was no correlation with the dosage of $L-T_{4}$ or the serum $T_{4}$ level. Treatment with sodium etidronate or calcitonin alone did not alter the regional BMD. Cyclical sodium etidronate, but not calcitonin, was able to prevent the bone loss induced by L-T treatment. $L-T_{4}$ caused a dose-dependent increase in femur osteocalcin mRNA concentration. Treatment with calcitonin resulted in $50 \%$ reduction of osteocalcin mRNA, but sodium etidronate had no effect. In conclusion, cyclical sodium etidronate prevents bone loss induced by exogenous $L-T_{4}$ in rats and may be useful in preventing osteoporosis in patients given long term TSH-suppressive doses of thyroxine therapy.
\end{abstract}

\section{INTRODUCTION}

T HYROID HORMONES have been shown to regulate normal bone maturation, as evidenced by the fact that hyperthyroidism or hypothyroidism in childhood is associated with abnormal growth and stature $(1,2)$. In adults, recent evidence shows that an excess of thyroid hormones affects the remodeling system in cortical and trabecular bone and may contribute to the development of osteoporosis (3). Thyroid hormone increases calcium release from fetal rat long bone cultures and increases osteoblast number and activity (4). In vivo, thyroid hormone also stimulates osteoblast activity (5). In hyperthyroidism the activation frequency of bone remodeling is increased, which results in an accelerated bone resorption and a concomitant increase in bone formation, with a marked shortening of both resorptive and formative phases of the remodeling cycle (6).
This results in a net reduction of bone mass. A number of studies confirmed that patients suffering from hyperthyroidism had lower bone mineral content at both cortical and trabecular bone (7). Furthermore, decrease in bone mineral densities (BMD) was similarly observed in subjects on physiologic or suppressive dosage of $L$-thyroxine treatment in some studies but not in others $(8,9)$.

It is still debatable whether adjunctive therapy is warranted to prevent rapid bone loss during thyroxine therapy, especially in postmenopausal women and older individuals who present with symptomatic or severe bone loss. Antiresorptive agents such as calcitonin and the diphosphonates that act by inhibiting osteoclast activity have been shown to prevent bone loss in patients with postmenopausal osteoporosis (10-13). The present study describes an animal model of thyroxine-induced bone loss and investigates whether these antiresorptive agents could prevent the decrease in BMD. 


\section{MATERIALS AND METHODS}

\section{Animals}

Male Sprague-Dawley rats of 8-10 weeks (320-350 g body weight) were chosen for study. They were housed in a room with controlled temperature $\left(22 \pm 1^{\circ} \mathrm{C}\right)$ and humidity $(65-70 \%)$. They were fed with normal diet (Ralston Purina) and allowed free access to tap water.

\section{Experimental design}

Groups of 10 rats each were treated for 3 weeks accordingly. Control rats received daily intraperitoneal (ip) injection of normal saline. Hyperthyroidism was induced by giving levothyroxine ( $\left(\mathrm{L}-\mathrm{T}_{4}\right.$, Sigma Chemical Co.) at doses of $0.1-0.3 \mathrm{mg} / \mathrm{kg}$ body weight ip daily, and hypothyroidism was induced by giving propylthiouracil (Sigma) as $0.1 \%(\mathrm{w} / \mathrm{v})$ solution per os (po). As for antiresorptive therapy, salmon calcitonin (Miacalcic, Sandoz Pharmaceutical, Switzerland) was given at $1 \mathrm{U} / \mathrm{kg}$ ip daily, and disodium etidronate (Didronel, Norwich Eaten, Austria) was given cyclically at a dose of $10 \mathrm{mg} / \mathrm{kg}$ po for 3 consecutive days per week. The dosage and regimen of the antiresorptive therapy were similar to those applied to human studies.

\section{Bone mineral density measurement}

Animals were anesthetized with sodium pentobarbital (Abbott), $50 \mathrm{mg} / \mathrm{kg}$ injected ip and did not move during scanning. Total body and regional bone mineral densities (BMD) were measured by the small animal scan program of Norland XR-26 bone densitometer (Fort Atkinson, Wisconsin), which is operated by the principle of dual energy X-ray absorptiometry (14). The accuracy and precision of estimating BMD in total animal in vivo were found to be $1 \%$. An ultrastable $\mathrm{X}$-ray source, operated at $100 \mathrm{kV}$ and $1 \mathrm{~mA}$, was used to provide the $\mathrm{X}$-ray beam that was then $\mathrm{K}$-edged ( $46.8 \mathrm{keV}$ ) by the samarium filtering module. This resulted in production of monochromatic $\mathrm{X}$-ray beams with two energies at approximately 45 and $80 \mathrm{keV}$. The dual energy beam was then scanned rectilinearly over the region of interest. The BMD was measured on a pixel-by-pixel basis and was calculated by a series of given iterations with an IBM PS-2 computer. The specially designed collimator and a special software were incorporated for the scanning of small animals. Bone scans were done on each animal for the total body, lumbar spine, tail, and right femoral region (Fig. 1). Regional BMDs were performed within a fixed area to assist in repeatable placement of cursors on follow-up scans. Bone densities were measured before and after 3 weeks of treatment. The whole set of experiment was carried out 3 times, each time with the same experimental design.

\section{RNA extraction and hybridization}

Rat femur was snap frozen in liquid nitrogen and RNA was extracted with guanidinium thiocyanate immediately after the muscle and periosteum were removed. The single step acid guanidinium-phenol-chloroform method was used to isolate the total cellular RNA (15). An oligonucleotide (5'-AGAGA-

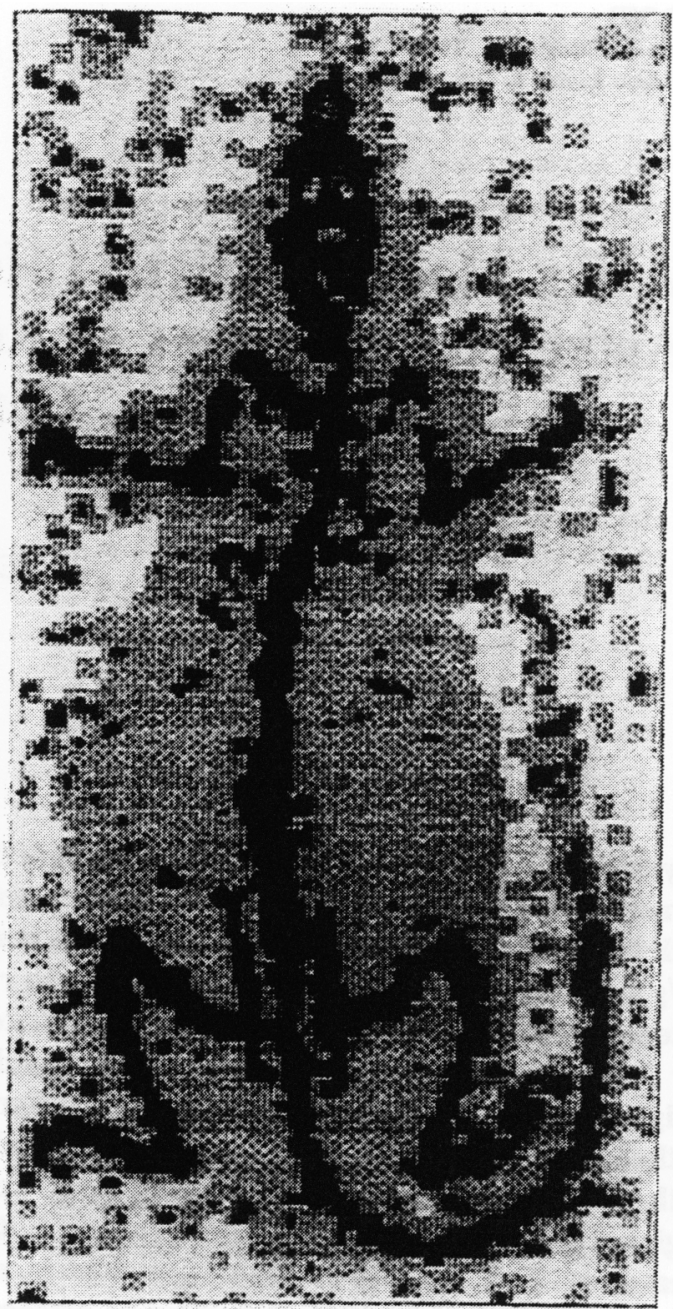

FIG. 1. Bone scan of the rat as determined by dual energy X-ray absorptiometry.

GAGGGTCCTCATGGT-3') was synthesized corresponding to the complementary sequences of the bases 1-20 of the rat osteocalcin cDNA (16). The oligonucleotide probe was 5' end-labeled with $\left[\gamma_{-}{ }^{32}\right.$-P]ATP and $\mathrm{T}_{4}$ polynucleotide kinase (Promega Corporation, Madison, WI). Hybridization was carried out overnight in $5 \times \mathrm{SSC}(0.3 \mathrm{M}$ sodium chloride- $0.03 \mathrm{M}$ sodium citrate), $20 \mathrm{mM}$ phosphate $\mathrm{pH} 7.0,10 \times$ Denhardt solution, $7 \%$ sodium dodecyl sulfate (SDS), and $10 \%$ dextran sulfate at $62^{\circ} \mathrm{C}$. Washing of the membrane was performed in $3 \times \mathrm{SSC}, 25 \mathrm{mM} \mathrm{PO}_{4}, \mathrm{pH} 7.5,10 \times$ Denhardt solution, 5\% SDS for $1 \mathrm{~h}$ at $57^{\circ} \mathrm{C}$ and then one wash in $1 \times \mathrm{SSC}, 1 \%$ SDS. The size of the rat osteocalcin mRNA was previously determined to be approximately $0.6 \mathrm{~kb}$. The hybridization signal was ascertained by scanning densitometry in an LKB instrument (Rockville, MD). The amount of total RNA loaded per lane was normalized to the amount of $28 \mathrm{~S}$ RNA, which was determined by staining the membrane with methylene blue.

\section{Thyroid function}

Blood was collected at termination of the experiment by cardiac puncture, and sera were stored at $-20^{\circ} \mathrm{C}$ until batch 
TABle 1. Thyroid FunCtion TESTS OF THE RATS ${ }^{a}$

\begin{tabular}{lcc}
\hline Group & Serum $T_{4}(\mu g / d L)$ & TSH $(\mathrm{ng} / \mathrm{mL})$ \\
\hline Control & $5.5 \pm 1.2$ & $0.43 \pm 0.26$ \\
$\mathrm{~T}_{4} 0.1 \mathrm{mg} / \mathrm{kg}$ & $8.7 \pm 2.3^{*}$ & $<0.05^{*}$ \\
$\mathrm{~T}_{4} 0.2 \mathrm{mg} / \mathrm{kg}$ & $16.2 \pm 3.6^{*}$ & $<0.05^{*}$ \\
$\mathrm{~T}_{4} 0.3 \mathrm{mg} / \mathrm{kg}$ & $20.8 \pm 6.9^{*}$ & $<0.05^{*}$ \\
Propylthiouracil & $<1.0^{*}$ & $3.6 \pm 0.65^{*}$ \\
\hline
\end{tabular}

${ }^{a}$ Results are mean $\pm \mathrm{SD} ; n=10$ in each group.

${ }^{*} p<0.05$ vs control.

assay. Serum $\mathrm{T}_{4}$ and $\mathrm{TSH}$ levels were measured by radioimmunoassay. Tracer and antibodies were obtained from ICN Biomedicals Inc. (Costa Mesa, CA).

\section{Statistics}

Comparison between groups was analyzed by one-way analysis of variance, and $p<0.05$ was considered as significant. Spearman's rank correlation was used to determine the relation between the dose and duration of $\mathrm{L}_{-} \mathrm{T}_{4}$ treatment with the regional BMDs.

\section{RESULTS}

\section{Effect of $L-T_{4}$ on $B M D$}

At baseline, all groups had similar body weight, total body bone mineral content (BMC), and regional BMDs. The mean total body BMC was $9.406 \pm 0.216$ (SD) $\mathrm{g}$, femur BMD was $0.117 \pm 0.002 \mathrm{~g} / \mathrm{cm}^{2}$, spine BMD was $0.113 \pm 0.003 \mathrm{~g} / \mathrm{cm}^{2}$, and tail BMD was $0.106 \pm 0.004 \mathrm{~g} / \mathrm{cm}^{2}$. After 3 weeks, body weight increased by $30 \%$ from $330 \pm 15 \mathrm{~g}$ to $437 \pm 95 \mathrm{~g}$ in the control rats. Total body BMC also increased by $11 \%$ to $10.478 \pm 0.263 \mathrm{~g}$. There was no significant change in linear growth (week $0,24.69 \pm 0.80 \mathrm{~cm}$ versus week 3, $25.80 \pm 0.56 \mathrm{~cm}) . \mathrm{L}_{-} \mathrm{T}_{4}$ treatment caused a dose-dependent elevation in the serum total $\mathrm{T}_{4}$ level (Table 1). All hyperthyroid rats had unmeasurable TSH levels. $\mathrm{L}_{-} \mathrm{T}_{4}$ treatment resulted in significant reduction in BMDs of the lumbar spine, tail, and femur (Table 2). However, there was no correlation between the regional BMDs and the dosage of $\mathrm{L}_{-} \mathrm{T}_{4}$ treatment or the serum $\mathrm{T}_{4}$ level. Propylthiouracil treatment reduced serum $\mathrm{T}_{4}$ level and also caused a significant decrease in body weight. A reduction in total body mineral content was seen but there was no significant change in the regional BMDs in these hypothyroid rats. However, when the results were adjusted for the body weight in these hypothyroid rats, the total body BMC as well as the BMDs of the femoral and lumbar spine but not the tail were significantly higher than the control rats [total body $\mathrm{BMC}, 28.17 \pm 2.73$ vs $23.12 \pm 0.72 \mathrm{~g} / \mathrm{kg}$ body weight (BW), $p<0.05$; femur BMD, $0.382 \pm 0.028$ vs $0.316 \pm 0.020 \mathrm{~g} / \mathrm{cm}^{2} / \mathrm{kg} \mathrm{BW}, p<0.05$ spine BMD, $0.455 \pm 0.055$ vs $0.332 \pm 0.020 \mathrm{~g} / \mathrm{cm}^{2} / \mathrm{kg} \mathrm{BW}$, $p<0.05$; tail $\mathrm{BMD}, \quad 0.299 \pm 0.014$ vs $0.265 \pm 0.029$ $\mathrm{g} / \mathrm{cm}^{2} / \mathrm{kg} \mathrm{BW}, p=\mathrm{NS}$, respectively].

\section{Effects of antiresorptive agent in BMDs}

$\mathrm{L}-\mathrm{T}_{4} 0.3 \mathrm{mg} / \mathrm{kg} \mathrm{BW}$ was chosen to study the effect of calcitonin and sodium etidronate on regional BMDs. Both sodium etidronate and calcitonin alone had no effect on regional BMDs. After treatment for 3 weeks, cyclical sodium etidronate treatment was able to prevent the reduction in BMDs induced by

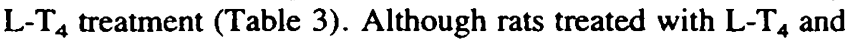
calcitonin had higher regional BMDs compared with $\mathrm{L}_{-} \mathrm{T}_{4}$ treatment alone ( $p=N S)$, they still had lower BMDs when compared with controls $(p<0.05)$.

\section{Osteocalcin mRNA}

L- $\mathrm{T}_{4}$ treatment caused a dose-dependent increase in femur osteocalcin mRNA concentration when compared with controls

TABle 2A. BONE DENSITY IN HYPERTHYROID AND HyPOTHYROID RATS $a$

\begin{tabular}{lccccc}
\hline Group & $B W(\mathrm{~g})$ & Total body BMC $(\mathrm{g})$ & Femur BMD $\left(\mathrm{g} / \mathrm{cm}^{2}\right)$ & Spine BMD $\left(\mathrm{g} / \mathrm{cm}^{2}\right)$ & Tail BMD $\left(\mathrm{g} / \mathrm{cm}^{2}\right)$ \\
\hline Control & $437 \pm 95$ & $10.478 \pm 0.263$ & $0.137 \pm 0.007$ & $0.144 \pm 0.009$ & $0.124 \pm 0.007$ \\
$\mathrm{~T}_{4} 0.1 \mathrm{mg} / \mathrm{kg}$ & $427 \pm 83$ & $10.450 \pm 0.395$ & $0.124 \pm 0.004^{*}$ & $0.126 \pm 0.006^{*}$ & $0.118 \pm 0.006^{*}$ \\
$\mathrm{~T}_{4} 0.2 \mathrm{mg} / \mathrm{kg}$ & $431 \pm 54$ & $10.279 \pm 0.299$ & $0.121 \pm 0.004^{*}$ & $0.123 \pm 0.010^{*}$ & $0.114 \pm 0.005^{*}$ \\
$\mathrm{~T}_{4} 0.3 \mathrm{mg} / \mathrm{kg}$ & $420 \pm 68$ & $10.391 \pm 0.278$ & $0.119 \pm 0.008^{*}$ & $0.122 \pm 0.010^{*}$ & $0.115 \pm 0.008^{*}$ \\
Propylthiouracil & $407 \pm 88^{*}$ & $10.006 \pm 0.069^{*}$ & $0.136 \pm 0.009$ & $0.148 \pm 0.010$ & $0.120 \pm 0.010$ \\
\hline
\end{tabular}

${ }^{a}$ Results are mean $\pm S D: n=10$ in each group.

${ }^{*} p<0.05$ vs control.

TABle 2B. Bone DENSITY OF HyPOTHYROID RATS AFTER ADJUSTMENT FOR BODY WEIGHT ${ }^{a}$

\begin{tabular}{lcccc}
\hline & $\begin{array}{c}\text { TBMC } / \text { weight } \\
(\mathrm{g} / \mathrm{kg})\end{array}$ & $\begin{array}{c}\text { Femur BMD/weight } \\
\left(\mathrm{g} / \mathrm{cm}^{2} / \mathrm{kg}\right)\end{array}$ & $\begin{array}{c}\text { Spine BMD/weight } \\
\left(\mathrm{g} / \mathrm{cm}^{2} / \mathrm{kg}\right)\end{array}$ & $\begin{array}{c}\text { Tail BMD/weight } \\
\left(\mathrm{g} / \mathrm{cm}^{2} / \mathrm{kg}\right)\end{array}$ \\
\hline Hypothyroidism & $28.17 \pm 2.73^{*}$ & $0.382 \pm 0.028^{*}$ & $0.455 \pm 0.055^{*}$ & $0.299 \pm 0.014$ \\
Control & $23.12 \pm 0.72$ & $0.316 \pm 0.020$ & $0.332 \pm 0.020$ & $0.265 \pm 0.029$ \\
\hline
\end{tabular}

${ }^{a}$ Results are mean \pm SD.

'TBMC, total body bone mineral content.

${ }^{*} p<0.05$. 
TAble 3. EfFect of ANTI Resportive Agent of Regional BMDs ${ }^{a}$

\begin{tabular}{lccc}
\hline Group & Femur BMD $\left(\mathrm{g} / \mathrm{cm}^{2}\right)$ & Spine BMD $\left(\mathrm{g} / \mathrm{cm}^{2}\right)$ & Tail BMD $\left(\mathrm{g} / \mathrm{cm}^{2}\right)$ \\
\hline Control & $0.137 \pm 0.007$ & $0.144 \pm 0.007$ & $0.124 \pm 0.007$ \\
$\mathrm{~T}_{4} 0.3 \mathrm{mg} / \mathrm{kg}$ & $0.119 \pm 0.008^{*}$ & $0.122 \pm 0.010^{*}$ & $0.115 \pm 0.008^{*}$ \\
$\mathrm{~T}_{4}+$ sodium etidronate & $0.131 \pm 0.006$ & $0.143 \pm 0.010$ & $0.119 \pm 0.008$ \\
$\mathrm{~T}_{4}+$ calcitonin & $0.123 \pm 0.005^{*}$ & $0.131 \pm 0.007^{*}$ & $0.112 \pm 0.007^{*}$ \\
Sodium etidronate & $0.140 \pm 0.008$ & $0.142 \pm 0.009$ & $0.126 \pm 0.006$ \\
Calcitonin & $0.138 \pm 0.008$ & $0.142 \pm 0.006$ & $0.123 \pm 0.009$ \\
\hline
\end{tabular}

${ }^{a}$ Results are mean $\pm \mathrm{SD}$.

${ }^{*} p<0.05$ vs control.

(Fig. 2). The densitometric results for $\mathrm{T}_{4} 0.1,0.2$, and 0.3 $\mathrm{mg} / \mathrm{kg}$ were $110 \pm 6,129 \pm 15$, and $175 \pm 20 \%$ of the control, respectively. In the hypothyroid rat osteocalcin mRNA concentration was reduced to $40 \pm 10 \%$ of the control. Treatment with calcitonin reduced osteocalcin mRNA to $50 \%$ of the control, whereas disodium etidronate did not affect osteocalcin gene expression. Treatment of the rats with both $\mathrm{L}-\mathrm{T}_{4} 0.3 \mathrm{mg} / \mathrm{kg}$ and calcitonin resulted in a steady state osteocalcin mRNA concentration of about $70 \%$ of the control (Table 4).

\section{DISCUSSION}

Our present data demonstrated that in rats exogenous thyroid hormone produced bone loss in the spine and femoral bones simulating its action in humans. Using the rat model for studies of bone metabolism is well documented, and models of human pathologies like aging (17), estrogen depletion (18), immobilization (19), and dietary calcium deficiency (20) have been established. The use of a noninvasive technique such as DEXA
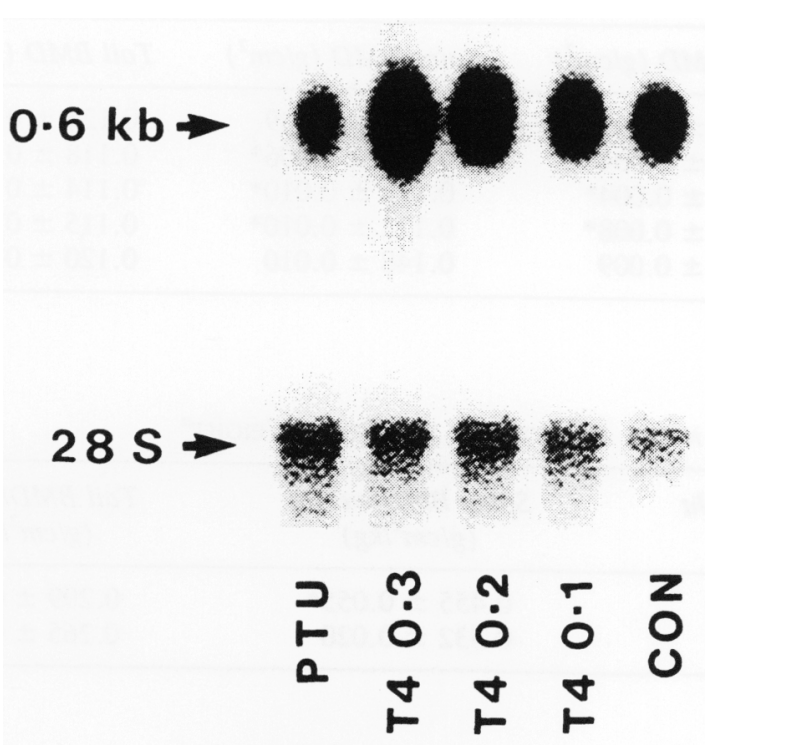

FIG. 2. Effect of thyroid hormone on osteocalcin mRNA level. for determination of BMD has also been varified in rats, with data correlating strongly with those obtained by ashing $(21,22)$. The pattern of bone loss in this rat model is similar to that observed in humans. It has been reported that thyroid hormone induced bone loss in appendicular bone in premenopausal women (23), while in postmenopausal subjects bone loss is observed in both appendicular and axial bone (24). The overall pattern of bone loss induced by exogenous thyroid hormone therapy is similar to that observed in patients with endogenous hyperthyroidism (25). Ongphiphadhanakul et al performed similar study and demonstrated that excessive $\mathrm{L}-\mathrm{T}_{4}$ therapy induced bone loss in the rat femur, except that they did not observe any change in the rat spine (26).

The pharmacopathology of thyroid hormone-induced bone loss is not well understood. Although both $T_{3}$ and $T_{4}$ dose dependently stimulate ${ }^{45} \mathrm{Ca}$ release from cultured fetal rat long bones in vitro (4), the effect is biphasic in mouse; higher doses of $T_{3}$ inhibit rather than stimulate calcium release (27). We observed that in patients on physiologic dose of $L-T_{4}$ replacement with normal thyroid function, the $Z$ score of the femoral neck correlated negatively with the serum-free thyroxine index (FTI) (8), whereas in patients on $\mathrm{L}-\mathrm{T}_{4}$ suppressive therapy with elevated serum FTI, no correlation was observed between the serum thyroid function and the regional BMD values or their $Z$ scores. This was also observed in our present hyperthyroid rat model, but the degree of bone loss did not correlate with the dose of $\mathrm{L}-\mathrm{T}_{4}$ given or the serum thyroid hormone level. Whether thyroid hormone also affects other growth factors that modulate bone remodeling awaits further confirmation. In the present

TABLE 4. EFFECT OF $\mathrm{LT}_{4}$ AND ANTIRESORPTIVE AGENTS ON OSTEOCALCIN MRNA ${ }^{a}$

\begin{tabular}{lc}
\hline Group & Densitometric unit (\%) \\
\hline Control & 100 \\
$\mathrm{~T}_{4} 0.1 \mathrm{mg} / \mathrm{kg} \mathrm{BW}$ & $110 \pm 6$ \\
$\mathrm{~T}_{4} 0.2 \mathrm{mg} / \mathrm{kg} \mathrm{BW}$ & $129 \pm 15^{*}$ \\
$\mathrm{~T}_{4} 0.3 \mathrm{mg} / \mathrm{kg} \mathrm{BW}$ & $175 \pm 20^{*}$ \\
Calcitonin & $50 \pm 10^{*}$ \\
$\mathrm{~T}_{4} 0.3 \mathrm{mg} / \mathrm{kg}+$ calcitonin & $70 \pm 15$ \\
Sodium etidronate & $90 \pm 20$ \\
$\mathrm{~T}_{4} 0.3 \mathrm{mg} / \mathrm{kg}+$ sodium etidronate & $158 \pm 16^{*}$
\end{tabular}

${ }^{a}$ Results are mean \pm SD.

${ }^{*} p<0.05$ vs control. 
study we also observed that in the hypothyroid rats, the adjusted regional BMDs were higher than controls. This finding has been reported in humans (28).

Thyroid hormone exerts its bone resorption activity via its action on the osteoblasts. Nuclear thyroid hormone receptors have been identified in rat osteosarcoma cell lines UMR-106 (29) and mouse osteoblast-like cell line MC3 T3-E1 (30). Also, human osteoblastic cell line MG63 has been shown to express $T_{3}$ receptor mRNA (31). Thyroid hormone receptors have not been identified in osteoclasts and there was no effect of $T_{3}$ on bone resorption by isolated osteoclasts (30). It is thus believed that the effect of thyroid hormone on osteoclastic bone resorption is indirectly mediated, and the osteoblast acts as the intermediary cell, thus resulting in a high turnover bone loss.

In this present rat model, we observed a positive relationship between serum $\mathrm{T}_{4}$ level and osteocalcin mRNA expression. This finding has also been reported previously (32). Osteocalcin is a noncollagenous bone matrix protein synthesized by osteoblasts and has been a useful clinical marker for increased bone turnover (33). Serum osteocalcin is increased in hyperthyroid patients (34) and in patients with multinodular goitre with suppressed TSH levels (35). We also observed in patients on long-term $\mathrm{L}^{-\mathrm{T}_{4}}$ suppressive therapy with elevated serum osteocalcin level, there was a negative correlation between the serum osteocalcin and the $Z$ score of the regional BMDs (9). Thus estimation of osteocalcin may be a sensitive way of identifying which patient is at particular high risk of developing osteoporosis. However, our study has not addressed how thyroid hormone increases steady-state osteocalcin mRNA. Osteocalcin transcription is stimulated by $1,25-(\mathrm{OH})_{2} \quad \mathrm{D}_{3}$ (36), but thyroid hormone has not been shown to increase osteocalcin transcription in transfection studies (37). The action of thyroid hormone probably does not depend on vitamin $D$ as hyperthyroidism is associated with a reduction in $1,25-(\mathrm{OH})_{2} \mathrm{D}_{3}$ levels both in man (38) and rats (39).

In this study we also examined the protective effect of antiresorptive agents against $\mathrm{L}_{\mathrm{T}} \mathrm{T}_{4}$-induced bone loss. The diphosphonate agent, sodium etidronate, but not calcitonin, was able to prevent $\mathrm{L}-\mathrm{T}_{4}$-induced bone loss both in the femoral and spinal region. Interestingly, the increase in osteocalcin mRNA expression induced by $\mathrm{L}-\mathrm{T}_{4}$ was not altered by disodium etidronate treatment but was reversed by calcitonin. The suppressive effect of calcitonin is also reflected at the translational level as Ongphiphadhanakul et al. reported a decrease in serum osteocalcin level in rats treated with calcitonin (26). The diphosphonates are nonbiodegradable analogues of pyrophosphate with a high binding affinity for hydroxyapatite crystals (40). They inhibit bone resorption by binding to bone surfaces and cause injury to the osteoclasts. Calcitonin, on the other hand, inhibits osteoclastic activity and motility ad reduces their cell number (41). The effect of these agents on bone formation is complex and it has not yet been established for certain whether they exert any effect on the osteoblast. For example, studies of the long-term effect of calcitonin on bone remodeling suggest that it lengthens the formation phase at the expense of the reversal phase between resorption and formation (42). This might be due to an indirect effect via osteoclasts or to a direct effect via osteoblasts. So far calcitonin receptor has only been found in the osteoclast but not osteoblast (43). Thus the observed inhibitory effect of calcitonin on osteocalcin gene expression is probably via an intermediary effect on osteoclasts, thus decreasing bone turnover. Although treatment of the thyrotoxic rats with calcitonin negated the effect of thyroxine on steady-state osteocalcin mRNA, the actions of $\mathrm{L}-\mathrm{T}_{4}$ and calcitonin on osteocalcin gene transcription are probably at different levels and require further elucidation. It is also of interest that despite the effectiveness of sodium etidronate in preventing bone loss, it has no effect on $\mathrm{L}_{-} \mathrm{T}_{4}$-induced elevation of osteocalcin mRNA concentration. Ongphiphadehanakul similarly reported that sodium etidronate was able to prevent the bone loss but not the increase in tartrate-resistant acid phosphatase induced by $L-\mathrm{T}_{4}(44)$.

Both calcitonin and sodium etidronate have been proven to be effective in the treatment of postmenopausal osteoporosis $(10-13)$. Thus it was surprising to observe in this study that calcitonin is ineffective in preventing bone loss induced by $\mathrm{L}-\mathrm{T}_{4}$, as calcitonin has in fact been demonstrated to be more effective in those osteoporotic patients with "high" turnover than in those with "low" turnover, as defined biochemically by an elevation of osteocalcin (45). The use of calcitonin in treatment high turnover bone loss is well illustrated by its effectiveness in treating Paget's disease (46). Thus, the role of antiresorptive agents in preventing thyroid hormone induced bone loss needs to be confirmed in human studies.

In conclusion, we have established a rat model of thyroid hormone induced bone loss. The diphosphonate agent, sodium etidronate, but not calcitonin, was able to prevent $\mathrm{L}-\mathrm{T}_{4}$-induced bone loss in the present model.

\section{ACKNOWLEDGMENTS}

The authors thank Dr. F. Tang for performing the $T_{4}$ assay and Ms Venus Yuen for secretarial assistance. The project was supported by CRCG Grant 335/041/0054, The University of Hong Kong. The work was presented in part at the 75th Annual Meeting of the Endocrine Society, Las Vegas, Nevada, June 1993.

\section{REFERENCES}

1. Simpson ME, Asling CW, Evans NM 1950 Some endocrine influences on skeletal growth and differentiation. Yale J Biol Med 23: 1-4.

2. Saxena KM, Crawford JD, Talbot NB 1964 Childhood thyrotoxicosis: A long-term perspective. Br Med J 2: 1153-1158.

3. Mosekilde L, Melsen F, Bagger JP et al. 1977 Bone changes in hyperthyroidism: Interrelationships between bone morphometry, thyroid function and calcium-phosphorus metabolism. Acta Endocrinol 85: 515-525.

4. Mundy GR, Shapiro JL, Bandelin JG, Canalis EM, Raisz LG 1976 Direct stimulation of bone resorption by thyroid hormones. J Clin Invest 58: 529-534.

5. Eriksen EF 1986 Normal and pathological remodeling of human trabecular bone: Three dimensional reconstruction of the remodeling sequence in normals and in metabolic bone disease. Endocr Rev 7: 379-398.

6. Melsen F, Mosekilde L 1977 Morphometric and dynamic studies of bone changes in hyperthyroidism. Acta Pathol Microbiol Scand (A) 85: 141-150.

7. Mosekilde L, Eriksen EF, Charles P 1990 Effects of thyroid hormones 
on bone and mineral metabolism. Endocrinol Metab Clin North Am 19: $35-62$.

8. Kung AWC, Pun KK 1991 Bone mineral density in premenopausal women receiving long-term physiological doses of levothyroxine. JAMA 265: 2688-2691.

9. Franklyn JA, Betteridge J, Daykin J, Holder R, Oates GD, Parle JV, Lilley J, Heath DA, Sheppard MC 1992 Long-term thyroxine treatment and bone mineral density. Lancet 340: 9-13.

10. Fatourechi V, Heath $\mathrm{HH}$ III 1987 Salmon calcitonin in the treatment of postmenopausal osteoporosis. Ann Intern Med 107: 923-925.

11. McDermott MT, Hidd GS 1987 The role of calcitonin in the development and treatment of osteoporosis. Endocr Rev 8: 377-390.

12. Storm T, Thamsborg G, Steiniche T, Genant HK, Sorenson OH 1990 The effect of etidronate therapy in postmenopausal osteoporotic women. N Engl J Med 322: 1265-1271.

13. Watts NB, Herris ST, Genants HK et al. 1990 Intermittent cyclical etidronate therapy of postmenopausal osteoporosis. N Engl J Med 323: 73-79.

14. Nord RH, Rayne PK, Hoonneman G 1989 Computation of bone density from dual energy x-ray data: An empirical methods. Presented at the XXI European Symposium on Calcified Tissue Jerusalem, Israel.

15. Chomcznski P, Sacchi N 1987 Single-step method of RNA isolation by acid guanidinium thiocyanate-phenol-chloroform extraction. Anal Biochem 162: 156-159.

16. Pan LC, Price PA 1985 The propeptide of rat bone $\gamma$-carboxyglutamic acid protein shares homology with other vitamin K-dependent protein precursors, Proc Natl Acad Sci USA 82: 6109-6113.

17. Simon MR 1984 The rat as an animal model for the study of senile idiopathic osteoporosis. Acta Anat 119: 248-250.

18. Silbermann M, Safadi M, Schapira D, Leichter I, Steinberg R 1989 Structural and compositional changes in aged bone: Osteopenia in lumbar vertebral of Wistar female rats. Scanning Microsc 3: 945-952.

19. Okumura H, Yamamuro R, Kasai R, Hayashi T, Tada K, Nishii Y 1987 Effect of $1 \alpha$ hydroxvitamin D3 on osteoporosis induced by immobilization combined with ovariectomy in rats. Bone 8: 351-355.

20. Bex F, Fallon M, Corbin A, Farber J, Maenner G, Wummer N 1987 Bone histology, density, and calcium regulatory hormone profile in chronically ovariectomized rats. J Bone Min Res 2(S1): 473 (abstract).

21. Kimmel DB, Wronski TJ 1990 Nondestructive measurements of bone mineral in femurs from ovariectomized rats. Calcif Tissue Int 46: $101-110$

22. Juhn A, Weiss A, Mendes D, Silbermann M 1991 Non-invasive assessment of bone mineral density during maturation and aging of Wistar female rats. Cells Materials Suppl 1: 19-24.

23. Paul TL, Kerrigan J, Kelly AM, Braverman LE, Baran DT 1988 Long term L-thyroxine therapy is associated with decrease hip bone density in premenopausal women. JAMA 259: 3137-3141.

24. Diamond T, Nevy L, Hales I 1991 A therapeutic dilemma: Suppressive doses of thyroxine significantly reduce bone mineral measurements in both premenopausal and postmenopausal women with thyroid carcinoma. J Clin Endocrinol Metab 72: 1184-1188.

25. Meunier PH, Bianchi GGS, Eduard CM et al. 1972 Bony manifestations of thyrotoxicosis. Orthop Clin North Am 3: 745-774.

26. Ongphiphadhanakul B, Alex S, Braverman LE, Baran DT 1992 Excessive L-thyroxine therapy decreases femoral bone mineral densities in the male rat: Effect of hypogonadism and calcitonin. J Bone Min Res 7: 1227-1231

27. Soskolne WA, Schwarts Z, Goldstein M, Ornoy A 1990 The biphasic effect of triiodothyronine compared to bone resorbing effect of PTH on bone remodelling of mouse long bone in vitro. Bone 11: 301-304.

28. Eriksen EF, Mosekilde L, Melsen F 1986 Kinetics of trabecular bone resorption and formation in hypothyroidism: Evidence for a positive balance per remodelling cycle. Bone 7: 101-105.

29. LeBron BA, Pekary AE, Mirell C, Hahn TJ, Hershman JM 1989
Thyroid hormone 5'-deiodinase activity, nuclear binding, and effects on mitogenesis in UMR-106 osteoblastic osteosarcoma cells. J Bone Min Res 4: 173-178.

30. Kasono K, Sato K, Han DC, Fujii Y, Tsushima T, Shizume K 1988 Stimulation of alkaline phosphatase activity by thyroid hormone in mouse osteoblast-like cells (MC3TE1): A possible mechanism of hyper-alkaline phosphatasia in hyperthyroidism. Bone Min 4: 355-358.

31. Allain TJ, Chambers TJ, McGregor Am 1992 Osteoblastic cells express mRNA for the triiodothyronine receptor and may mediate osteoclastic bone resorption in response to triiodothyronine. 74th Annual Meeting, the Endocrine Society, San Antonio, Texas. Abstract 655.

32. Ross DS, Graichen R 1991 Increased rat femur osteocalcin mRNA concentrations following in vivo administration of thyroid hormone. $J$ Endocrinol Invest 14: 763-766.

33. Epstein S 1988 Serum and urinary markers of bone remodeling: Assessment of bone turnover. Endocr Rev 9: 437-449.

34. Lukert BP, Higgins JC, Stoskopf MM 1986 Serum osteocalcin is increased in patients with hyperthyroidism and decreased in patients receiving glucocorticoids. J Clin Endocrinol Metab 62: 1056-1058.

35. Faber J, Perrild H, Johansen JS 1990 Bone Gla protein and sex hormone-binding globulin in nontoxic goitre: Parameters for metabolic status at the tissue level. J Clin Endocrinol Metab 70: 49-55.

36. Lian J, Stewart C, Puchacz E et al. 1989 Structure of the rat osteocalcin gene and regulation of vitamin D-dependent expression. Proc Natl Acad Sci USA 86: 1143-1147.

37. Morrison NA, Shine J, Fragonas JC, Verkest V, McMenemy ML, Eisman JA 1989 1,25-dihydroxyvitamin D-responsive element and glucocorticoid repression in the osteocalcin gene. Science 246: 1158-1161 .

38. Bouillion R, Muls E, Ee Moor P 1980 Influence of thyroid function on the serum concentration of 1,25-dihydroxyvitamin D3. J Clin Endocrinol Metab 51: 793-797.

39. Weisman Y, Eisenberg Z, Lubelski R, Spirer Z, Edelstein S, Harell A 1981 Decreased 1,25-hydroxycholecalciferol and increased 25-hydroxy- and 24,25-dihydroxycholecalciferol in tissues of rats treated with thyroxine. Calcif Tissue Int 33: 445-448.

40. Jung A, Bisaz S, Fleish H 1973 The binding of pyrophosphate and two diphosphonate on hydroxyapatite crystals. Calcif Tissue Res 11: 269-280.

41. Accardo Get al. 1982 Support for the clinical use of calcitonin: Electron microscope study of the functional state of bone cells of rats after chronic treatment with calcitonin. Cur The Res Clin Exp 31: 422-433.

42. Baron R, Saffar JL 1977 A quantitative study of the effects of prolonged calcitonin treatment on alveolar bone remodeling in the golden hamster. Calcif Tissue Res 22: 265-274.

43. Nicholson GC, Moseley JM, Sexton PM et al. 1986 Abundant calcitonin receptors in isolated rat osteoclasts. J Clin Invest 78: 355-360.

44. Ongphiphadhanakul B, Alex S, Braverman L, Baran D 1992 Intermittent etidronate administration prevents the thyroid hormone induced decrease in bone mineral density in the rat. Clin Res 40: abstract 165.

45. Civitelli R, Gonneli S, Zacchei $F$ et al. 1988 Bone tumover in postmenopausal osteoporosis. J Clin Invest 82: 1268-1274.

46. Williams CP, Meachim G, Taylor WH 1978 Effect of calcitonin treatment on osteoclast counts in Paget's disease of bone. J Clin Pathol 31: $1212-1217$.

Address reprint requests to: Annie W.C. Kung

Department of Medicine

The University of Hong Kong Queen Mary Hospital Pokfulam Road Hong Kong 